\title{
Peningkatan Kesejahteraan Masyarakat Melalui Kualitas Layanan, Citra Organisasi Kepuasan dan Loyalitas Anggota Credit Union Betang Asi di Kalimantan Tengah
}

\author{
Lelo Sintani \\ (1) Fakultas Ekonomi dan Bisnis Universitas Palangka Raya \\ lelosintani@gmail.com
}

\begin{abstract}
Abstrak.
Tujuan pembangunan di Indonesia adalah untuk mencapai kemakmuran dan kesejahteraan bagi masyarakat sehingga pemerintah dituntut dapat menciptakan iklim usaha yang kondusif. Agar masyarakat dapat terbebas masalah ekonomi seperti kemiskinan, pengangguran, ketidakmerataan pendapatan, produktivitas rendah hingga ekonomi biaya tinggi. Usaha Mikro, Kecil dan Menengah (UMKM) mempunyai peran penting dan strategis dalam pembangunan ekonomi nasional dan mengatasi masalah ekonomi. Namun ada 60-70\% pelaku UMKM belum memiliki akses pembiayaan perbankan. Dalam rangka mempermudah akses permodalan kepada UMKM maka Koperasi Kredit termasuk Kopdit CU Betang Asi sebagai lembaga Keuangan Bukan Bank (LKBB) berperan penting. Kualitas Layanan, Citra Organisasi, Kepuasan dan loyalitas pelanggan yang baik merupakan indikator bahwa organisasi tersebut berperan dalam pembangunan ekonomi.Tulisan ini bertujuan untuk mengukur dan menganalisis pengaruh kualitas layanan, citra organisasi, kepuasan terhadap loyalitas anggota Koperasi Kredit CU Betang Asi di Kalimanatan Tengah. Metode penelitian menggunakan metode kuantitatif dengan populasi seluruh anggota CU Betang Asi di Kalimanatan Tengah sebanyak 39.294 orang dengan jumlah sampel sebanyak 405 orang dengan teknik penetapan jumlah sampel 15 kali jumlah indikator. Alat analisis menggunakan analisis deskriptif dan analisis PLS. Hasil analisis membuktikan bahwa layanan berkualitas diukur dari dimensi bukti fisik, Keandalan, tanggapan, jaminan, dan empati, citra organisasi baik, anggota puas dan loyal dibuktikan dari nilai mean 4 keatas dari seluruh indikator variabel. Berdasarkan hasil analisis PLS terbukti bahwa citra organisasi berpengaruh signifikan terhadap kepuasan anggota dan loyalitas anggota. Kualitas layanan berpengaruh signifikan terhadap kepuasan anggota tetapi tidak berpengaruh signifikan terhadap loyalitas anggota. Demikian juga kepuasan anggota tidak berpengaruh terhadap loyalitas anggota.
\end{abstract}

Kata kunci: Kualitas Layanan, Citra Organisasi, Kepuasan dan Loyalitas

Abstract.

The goal of Indonesia development is to reach prosperity and welfare for the all Indonesians that the government is required to create a conducive business climate. It is held to overcome the economic problems of Indonesia society such as poverty, unemployment, income inequality, low productivity and high cost of economy. Usaha Mikro, Kecil dan Menengah (known as UMKM in Indonesia) or micro scale, small scale and middle scale of enterprises have an important and strategic role in national economic development and overcome economic problems. Yet there are 60$70 \%$ of UMKM's that have not had access to bank financing. In order to facilitate the capital access to UMKM, the credit cooperation such as CU Betang Asi as a non-bank financial organization plays a crucial role as well. Better quality of service, organization image, member satisfaction and loyalty is an indicator that the organization plays a role in economic development. This paper aims to measure and analyze the influence of service quality, organizational image, satisfaction on the loyalty of members of the Betang Asi Credit Union in Central Kalimantan. The research method used is quantitatif method with a population of all members of CU Betang Asi in Central Kalimantan as many as 39,294 people with a sample size of 405 people with the technique of determining the number of samples 15 times the number of indicators. The analysis tool uses descriptive analysis and PLS analysis. The results of descriptive analysis prove that quality service is measured from the dimensions of physical evidence, reliability, response, assurance, and empathy, good organizational image, satisfied and loyal members as evidenced by the mean value of 4 and above of all variable indicators. Based on the results of PLS analysis, it is proven that organizational image has a significant effect on member satisfaction and member loyalty. Service quality has a significant effect on member satisfaction but does not have a significant effect on member loyalty. Likewise, member satisfaction has no effect on member loyalty.

Keywords: service quality, organization image, satisfaction and Loyalty 


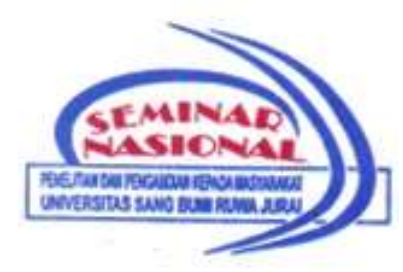

\section{PENDAHULUAN}

Pendahuluan (tanpa sub-bagian, 10\% dari total halaman) meliputi latar belakang, tujuandan tinjauan literatur / konstruksi teoritis jika perlu) dari penelitian. Bagian pengantar diakhiri dengan penekanan pada hal-hal yang akan dibahas. Pendahuluan terdiri dari latar belakang penelitian yang menjelaskan fenomena aktual yang telah diselidiki, didukung oleh referensi dan studi sebelumnya yang telah dilakukan secara individu atau dalam kelompok atau tim. Penulis juga harus menjelaskan keberadaan penelitian ini dibandingkan dengan penelitianpenelitian sebelumnya. Pendahuluan terdiri dari masalah (satu masalah yang menjadi fokus penelitian lebih baik), tujuan penelitian, signifikansi penelitian, dan teori yang digunakan untuk memecahkan masalah. Semua sumber yang dikutip atau diparafrasekan harus ditulis dalam daftar referensi. Pendahuluan tidak mengizinkan sub-bab.

Pembangunan Nasional jangka panjang bertujuan dapat menghantarkan masyarakat Indonesia kepada kemakmuran dan kesejahteraan. Sehingga pemerintah dituntut dapat menciptakan iklim usaha yang kondusif dan mendorong dan memfasilitasi masyarakat untuk dapat mengatasi permasalahan ekonomi mereka melalui berbagai kebijakan. Usaha untuk mencapai tujuan pembangunan nasional tersebut maka perlu menoptimalkan peran dari Usaha Mikro, Kecil dan Menengah (UMKM) melalui pertumbuhan ekonomi dan penyerapan tenaga kerja,dan mendistribusikan hasil-hasil pembangunan. UMKM merupakan pasar yang sangat potensial bagi industri jasa keuangan, untuk menyalurkan pembiayaan.

Menurut data dari Bank Indonesia tahun 2017 sekitar 60-70\% UMKM belum mendapat akses atau pembiayaan dari perbankan. Padahal UMKM memiliki proporsi kurang lebih $90 \%$ lebih dari total keseluruhan pelaku usaha Indonesia atau sebanyak sekitar 56,54 juta unit usaha. Permodalan menjadi masalah bagi UMKM mengakibatkan pelaku UMKM kesulitan dalam meningkatkan kapasitas usahanya atau mengembangkan produk agar mampu bersaing.

Lembaga keuangan yang menyalurkan pembiayaan bagi UMKM dapat dikelompokkan dalam dua bentuk yaitu lembaga keuangan bank (Bank) dan lembaga keuangan bukan bank (LKBB). Koperasi simpan pinjam (KSP) atau koperasi Kredit (KOPDIT) karena usaha yang dijalankan yaitu menghimpun dana dari anggota koperasi dan menyalurkan kembali kepada anggota koperasi. Dalam rangka mempermudah akses permodalan untuk meningkatkan peran UMKM bagi pembangunan ekonomi maka Koperasi Kredit sebagai lembaga Keuangan Bukan Bank (LKBB) berperan penting untuk membantu penyediaan modal bagi UMKM. Bentuk lembaga keuangan koperasi sangat sesuai dengan jiwa bangsa Indonesia dan dapat diakses oleh kalangan masyarakat menengah ke bawah. Koperasi mampu memberikan peran untuk mengurangi ketergantungan pengusaha mikro, kecil dan menengah dari lembaga keuangan/permodalan konvensional.

Koperasi khususnya koperasi kredit sebagai lembaga keuangan yang berperan untuk menyalurkan dana bagi UMKM juga masih menghadapi permasalahan yaitu dari kelembagaan, administrasi, usaha, dan permodalan. Untuk itu diperlukan reformasi untuk perbaikan koperasi di Indonesia. Ada tiga hal yang dilakukan untuk perbaikan untuk mengembalikan citra koperasi, yaitu rehabilitasi, reorientasi dan pengembangan koperasi.

Layanan berkualitas, citra baik koperasi akan mampu meningkatkan kepercayaan masyarakat dan meningkatkan loyalitas anggota koperasi dan pada akhirnya akan 
meningkatkan peran serta koperasi dalam penyediaan modal bagi usaha mikro menengah (UMKM).

Secara empiris terbukti bahwa kualitas pelayanan dan citra berpengaruh positif terhadap kepuasan pelanggan dan Loyalitas pelanggan. Juga membuktikan bahwa kepuasan pelanggan memediasi pengaruh citra terhadap loyalitas pelanggan (Safitri dkk, 2015). Andreassen dan Lindestad, 1998, juga membuktikan bahwa Citra Perusahaan berhubungan positif dengan produk dan kualitas layanan, dan

kepuasan pelanggan industri. Saravanakumar, 2014 melakukan melakukan penelitian pada bank-bank yang memberikan pinjaman kepada masyarakat pedesaan untuk stabilitas ekonomi masyarakat desa. Hasil penelitian membuktikan bahwa kualitas pelayanan memiliki berpengaruh terhadap loyalitas pelanggan. Selanjutnya empati dan kehandalan adalah dimensi yang secara signifikan mempengaruhi loyalitas pelanggan. Hasil penelitian ini didukung oleh penelitian Mosahab dan 2010, Koestanto, 2014.

Koperasi simpan pinjam Credit Union Betang Asi merupakan lembaga keuangan yang bergerak dalam jasa keuangan yang menjalankan usahanya yaitu dengan cara menghimpun dana dalam bentuk tabungan, deposito dan menyalurkannya dengan prosedur yang mudah dan cepat. memegang peranan penting sebagai alternatif lembaga keuangan yang efektif untuk menjangkau kalangan usaha mikro, kecil dan menengah.

Kopdit CU Betang Asi sebagai koperasi simpan pinjam yang melayani masyarakat terutama masyarakat ekonomi kelas menengah bawah dan sebagian besar tinggal di pedesaan, diharapkan mampu memberikan layanan yang berkualitas dan memuaskan bagi anggotanya. Hal ini diharapkan dapat menunjang dan memperbaiki perekonomian masyarakat pedesaan dan pada akhirnya dapat meningkatkan kesejahteraan masyarakat. Penelitian ini adalah untuk mengukur kualitas layanan, Citra, kepuasan anggota dan Loyalitas Anggota CU Betang Asi di Kalimanatan Tengah.

\section{Kajian Pustaka}

Wyckof dalam Anatan (2008) mengemukakan bahwa kualitas layanan merupakan tingkat keunggulan yang diharapkan dan pengendalian atas tingkat keunggulan tersebut untuk memenuhi harapan pelanggan. Dan Nasution (2004) mengungkapkan bahwa kualitas mencakup usaha memenuhi atau melebihi harapan pelanggan dan kualitas merupakan konsisi yang selalu berubah. Terdapat lima kelompok karakteristik yang digunakan oleh konsumen dalam mengevaluasi ataupun menilai suatu kualitas pelayanan jasa yaitu sebagai berikut: keandalan (realibility) adalah kemampuan untuk memberikan pelayanan yang sesuai fungsi yang ditawarkan, ketanggapan atau daya tanggap (responsivenes) adalah kesigapan karyawan dalam membantu konsumen dan 8memberikan pelayanan informasi dengan cepat, jaminan (assurance) adalah untuk mengukur kemampuan dan kesopanan karyawan serta sifat yang dapat dipercaya yang dimiliki oleh karyawan, bukti langsung (tangibles) yang meliputi penampilan fisik, kebersihan dan kerapian karyawan serta kelengkapan komunikasi, Empathy adalah tatacara yang digunakan penyelenggara pelayanan untuk menunjukkan rasa pedulidan perhatian kepada konsumen (Tjiptono, 2008). 
Kotler dan Keller (2009) mengemukakan bahwa kepuasan (satisfaction) adalah perasaan senang atau kecewa seseorang yang timbul karena membandingkan kinerja yang dipersepsikan produk (atau hasil) terhadap ekspektasi mereka. Jika kinerja gagal memenuhi ekspektasi, pelanggan akan tidak puas. Jika kinerja sesuai dengan ekspektasi, pelanggan akan puas. Jika kinerja melebihi ekspektasi, pelanggan akan sangat puas. Manfaat-manfaat kepuasan pelanggan bagi perusahaan mencakup: dampak positif terhadap loyalitas pelanggan; berpotensi menjadi sumber pendapatan masa depan melalui pembelian ulang, cross-selling dan up-selling; menekan biaya transaksi pelanggan dimasa depan terutama biaya-biaya komunikasi, penjualan, dan layanan pelanggan; Tjiptono (2008: 30) mendefinisikan kepuasan konsumen atau pelanggan sebagai evaluasi secara sadar atau penilaian kognitif menyangkut apakah kinerja produk relatif bagus atau jelek apakah produk atau jasa bersangkutan cocok atau tidak cocok dengan tujuan atau pemakaiannya.

Kotler, 2008 menjelaskan bahwa citra perusahaan adalah respon konsumen pada keseluruhan penawaran yang diberikan perusahaan dan didefinisikan sebagai sejumlah kepercayaan, ide-ide, dan kesan masyarakat pada suatu organisasi. Jadi Citra dapat dikatakan sebagai persepsi masyarakat dari adanya pengalaman, kepercayaan, perasaan, dan pengetahuan masyarakat itu sendiri terhadap perusahaan, sehingga aspek fasilitas yang dimiliki perusahaan, dan layanan yang disampaikan karyawan kepada konsumen dapat mempengaruhi persepsi konsumen terhadap citra. Selanjutnya menurut Kotler dan Keller (2009: 340) Citra merek berhadapan dengan properti ekstrinsik dari produk atau jasa, termasuk cara merek itu memenuhi kebutuhan sosial atau psikologis anggota. Dalam hal ini citra merek adalah persepsi masyarakat akan keyakinanya terhadap koperasi atau produk atau jasa

Oliver dalam Kotler (2009: 138) mendefinisikan loyalitas (loyalty) sebagai komitmen yang dipegang secara mendalam untuk membeli atau mendukung kembali produk atau jasa yang disukai dimasa depan meski pengaruh situasi dan usaha pemasaran berpotensi menyebabkan pelanggan beralih. Menurut Alma (2014: 274) karakteristik dari loyalit ialah konsumen melakukan pembelian ulang secara teratur/regular. Mereka juga membeli produk-produk lain bukan satu produk saja yang ditawarkan oleh produsen. Mereka merekomendasi teman-temannya untuk juga membeli produk yang sama ketempat yang sama, dan mereka tidak mudah beralih ke produk saingan.

Beberapa kajian empiris terdahulu juga membuktikan bahwa ada pengaruh signifikan antara kualitas layanan, citra, kepuasan dan loyalitas pelanggan baik sektor jasa perbankan, jasa perdagangan dan koperasi

Safitri dkk, 2015, Menguji pengaruh kualitas layanan dan citra terhadap kepuasan dan loyalitas pelanggan Sampel dalam penelitian ini adalah dan metode pengambilan sampel purposive sampling. Jumlah responden yang berpartisipasi dalam penelitianini sebanyak 140 responden. Alat analisis adalah Partial Least Square(PLS) -Structural Equation Model (SEM) untuk menguji hipotesis. Hasil penelitian ini menunjukkan bahwa kualitas pelayanan memiliki pengaruh yang signifikan terhadap kepuasan pelanggan, citra perusahaan berpengaruh signifikan terhadap kepuasan pelanggan, kualitas layanan berpengaruh signifikan terhadap loyalitas pelanggan, citra perusahaan berpengaruh signifikan terhadap loyalitas pelanggan, kepuasan pelanggan berpengaruh signifikan terhadap loyalitas pelanggan, serta kepuasan pelanggan memediasi pengaruh kualitas layanan ke loyalitas pelanggan, dan kepuasan pelanggan memediasi pengaruh citra perusahaan ke loyalitas pelanggan.Andreassen dan Lindestad, 1998, The effect of corporate image in the formation of customer loyality, Alat analisis menggunakan analisis Structural Equation Model (SEM). Hasil penelitian menemukan bahwa Citra Perusahaan 
berhubungan positif dengan produk dan kualitas layanan, selanjutnya citra perusahaan berkorelasi positif dengan kepuasan pelanggan industry.

Mosahab, 2010, Service Quality, Customer Satisfaction and Loyalty: A Test of Mediation. Penelitian ini dilakukan di sebuah bank di Teheran, Iran, pada 2009-2010. Laporan ini merupakan hasil dari penelitian lapangan, yang bertujuan untuk menentukan kualitas layanan yang ditawarkan oleh Bank Sepah, dan juga untuk mempelajari hubungan antara kualitas pelayanan, kepuasan dan loyalitas. Dalam penelitian ini, model standar kualitas pelayanan telah digunakan untuk evaluasi kualitas layanan, Gremler dan Brown (1996) model dengan beberapa revisi itu digunakan untuk mengevaluasi loyalitas, dan instrumen yang ditawarkan oleh Bitner dan Hubbert (1994) digunakan untuk evaluasi kepuasan pelanggan. Fokus penelitian ini adalah cabang Bank Sepah Teheran, Iran, dan 147 nasabah bank ini diambil untuk sampelnya. Hasil penelitian ini menunjukkan bahwa dalam semua aspek, harapan pelanggan, lebih tinggi dari persepsi mereka terhadap operasional Bank, dan pada kenyataannya kualitas layanan yang ditawarkan rendah. Selain itu, hasil penelitian ini menunjukkan bahwa kepuasan pelanggan memainkan peran mediator dalam efek dari kualitas pelayanan terhadap loyalitas layanan.

Saravanakumar, 2014 Effect Of Service Quality On Customer Loyalty: Empirical Evidence From Co-Operative Bank. Bank-bank yang memberikan pinjaman kepada masyarakat pedesaan untuk stabilitas ekonomi mereka. Namun, kualitas layanan bank harus dianalisis dari sudut pandang pelanggan pedesaan. Oleh karena itu, penelitian ini adalah untuk mengetahui pengaruh kualitas pelayanan Bank dan loyalitas nasabah. Untuk itu diambil sampel 415 nasabah Koperasi Bank di District Thanjavur, Tamil Nadu. Dimensi kualitas layanan yang digunakan yaitu tangibility, reliability, responsiveness, jaminan dan empati untuk mengukur kualitas pelayanan bank. Loyalitas pelanggan diukur dengan lima pernyataan. Data yang dikumpulkan dianalisis dengan statistik deskriptif, korelasi dan analisis regresi. Hasil penelitian menunjukkan bahwa kualitas pelayanan memiliki dampak terhadap loyalitas pelanggan. Namun, empati dan kehandalan adalah dimensi yang secara signifikan mempengaruhi loyalitas pelanggan. Hal ini menunjukkan bahwa bank harus meningkatkan pelayanan dalam hal tangibility, tanggung jawab dan jaminan. Meti Duwiyanti, 2014, dalam penelitiannya analisis pengaruh kualitas layanan dan kepuasan anggota pada koperasi Bahagia Jaya Gubeng Surabaya. Hasil penelitian membuktikan kualitas pelayanan pengaruh yang positif dan terhadap kepuasan dan loyalitas anggota dan kepuasan anggota juga berpengaruh positif dan signifikan terhadap loyalitas anggota.

Valentine Aprillia Nugraheni, 2017 dalam penelitiannya Pengaruh citra perusahaan, kualitas layanan, dan kepuasan pelanggan terhadap loyalitas pelangganKoperasi Setia Bhakti Surabaya. Hasil penelitian ini menunjukkan bahwa citra perusahaan, kualitas layanan, dan kepuasan pelanggan berpengaruh positif dan signifikan terhadap loyalitas pelanggan, karena citra perusahaan, kualitas layanan, dan kepuasan pelanggan.

\section{METODE PENELITIAN}

Penelitian ini menggunakan metode deskriptif yaitu pencarian fakta dengan metode yang tepat, yang bertujuan untuk membuat diskripsi, gambaran atau lukisan secara sistematis, faktual dan akurat mengenai Kualitas Layanan, Citra Organisasi, Kepuasan dan Loyalitas anggota Koperasi Kredit CU Betang Asi di Kalimantan Tengah. Populasi dalam penelitian ini adalah seluruh Anggota dari CU Betang Asie yang ada di Kalimantan Tengah. Adapun jumlah CU Betang Asie terdiri dari 8 tempat Pelayanan (TP) dan 11 Tempat Pelayanan Khusus (TPK) sebanyak 39.294 orang (CU Betang Asi, Desember 2016). Teknik Penetapan jumlah sampel merujuk kepada pendapat Ferdinand, 2014 yaitu minimal 10 kali jumlah indikator sehingga 
penelitian ini mengambil 15 kali jumlah indikator yaitu $15 \times 27$ indikator sehingga jumlah sebesar 405 orang. Teknik pengmbilan sampel yang digunakan adalah metode porpusive sampling.

Definisi Operasional variabel- variabel penelitian yaitu kualitas Pelayanan adalah tingkat keunggulan dari produk atau jasa yang diharapkan dan dirasakan oleh anggota CU yang untuk memenuhi harapan anggota. Kualitas layanan ini diukur dengan 5 dimensi yaitu bukti fisik, keandalan, ketanggapan, jaminan dan empati. Citra perusahaan adalah respon anggota pada keseluruhan penawaran yang diberikan CU Betang Asi dengan indicator dikenal oleh masyarakat, mudah diingat, merasa aman menyimpan dana di CU Betang Asi dan lebih udah dlm proses tabungan dan pinjaman

Kepuasan anggota adalah perasaan senang atau kecewa dari anggota CU Betang Asi yang timbul setelah membandingkan harapan dengan kinerja dengan indicator staf melayani sesuai dengan yang diharapkan, fasilitas pelayanan memuaskan dan manfaat yang diterima secara keseluruhan memuaskan

Loyalitas Anggota adalah sikap dan perilaku anggota yang puas dan sangat puas dengan produk dan pelayanan CU Betang Asi sehingga mempunyai antusiasme untuk memperkenalkannya kepada siapapun yang mereka kenal dengan indicator tidak ingin untuk berpindah ke lembaga lain, merekomendasikan kepada orang lain untuk menjadi anggota CU Betang Asi dan yakin menjadi anggota CU Betang Asi adalah pilihan yang tepat Jenis data digunakan adalah data primer dan data sekunder. Dan untuk mengukur seluruh varibel menggunakann Skala Likert dengan skala $1-5$. Untuk memastikan istrumen penelitian sudah sahih dan handal maka dilakukan u ji validitas dan Reliabilitas. Untuk menguji validitas rumus Pearson dengan korelasi Product Moment. Syarat minimun untuk dianggap valid adalah nilai $r$ > 0,30. Pengujian reliabilitas dengan menghitung Alpha Croanbach $\geq 0,6$. Teknik analisis data menggunakan Analisis Diskriptif dan analisis inferensial menggunakan Partial Least Square (PLS).

\section{HASIL DAN PEMBAHASAN}

\section{Analisis Deskriptif}

Untuk mendapatkan gambaran tentang kualitas layanan, citra, kepuasan dan loyalitas berdasarkan penilaian dari anggota diukur dengan analisis deskriptif yang dilihat dari nilai frekwensi, prosentase dan mean. Hasil analisis deskriptif ini dapat menjelaskan gambaran variabel-variabel penelitian ini.

Layanan yang diberikan Kopdit CU Betang Asi dinilai anggota sudah berkualitas dengan nilai mean 4,3612 demikian juga untuk tiap dimensi dan indikatornya juga dinilai sudah berkualitas dengan nilai mean diatas 4 . Jika dilihat dari nilai mean setiap dimensi maka empati memiliki nilai mean paling rendah, artinya dimensi empati dinilai anggota kurang berkualitas dibandingkan dimensi yang lain. Hal ini perlu menjadi perhatian bagi pengurus dan manajemen.

Anggota Kopdit CU Betang Asi menilai bahwa layanan yang diberikan sudah memuaskan dibuktikan dengan nilai mean variabel kepuasan anggota sebesar 4, 2647 dannilai mean seluruh indikator variabel juga diatas 4. Namun jika dilihat setiap indikator maka indikator situasi pelayanan rendah dibandingkan indikator lainnya. Sehingga organisasi perlu lebih memperhatikan situasi pelayanan. 
Anggota Kopdit CU Betang Asi menilai bahwa mereka sudah loyal terhadap Kopdit CU Betang Asi dibuktikan dengan nilai mean sebesar 4,3261. Namun jika dilihat setiap indikator maka indikator tidak ingin berpindah dari CU Betang Asi memiliki mean terendah dibandingkan yang lain. Jadi pengurus dan manajemen perlu memikirkan untuk menyediakan produk dan layanan yang lebih baik agar anggota tetap loyal pada CU Betang Asi.

Persepsi anggota Citra Kopdit CU Betang Asi baik dibuktikan dengan nilai mean sebesar 4,3261. Jika dilihat nilai mean masing-masing indikator maka indikator pelayanan pinjaman mudah mean terendah, artinya pihak pengurus dan manajemen perlu meninjau kembali persyaratan dan proses pemberian pinjaman kepada anggota.

\section{Analisis Inferensial}

Untuk mengukur kontribusi dari masing-masing indikator terhadap variabel dan untuk uji convergent validity yang dilihat dari nilai outher loading. Hasil uji menunjukkan nilai outher loading indikator dari setiap variabel diatas 0,7 berarti setiap indikator variabel sudah tepat untuk mengukur variabel tersebut.

Nilai composite reliability $>0,6$ dan nilai average variance extract (AVE) $>0,5$ berarti semua variabel dalam model penelitian ini reliable.

Pengujian goodness of fit untuk mengetahui kemampuan variabel eksogen menjelaskan variasi variabel endogen ( yang dilihat dari nilai $\mathrm{R}$ Square $\left(\mathrm{Q}^{2}\right)$ sebesar 0,588 artinya bahwa model penelitian ini baik dan layak

Untuk menguji pengaruh antar variabel dalam hal ini pengaruh dari kualitas layanan dan citra organisasi terhadap kepuasan dan loyalitas anggota kopdit CU Betang Asi menggunakan analisis PLS.

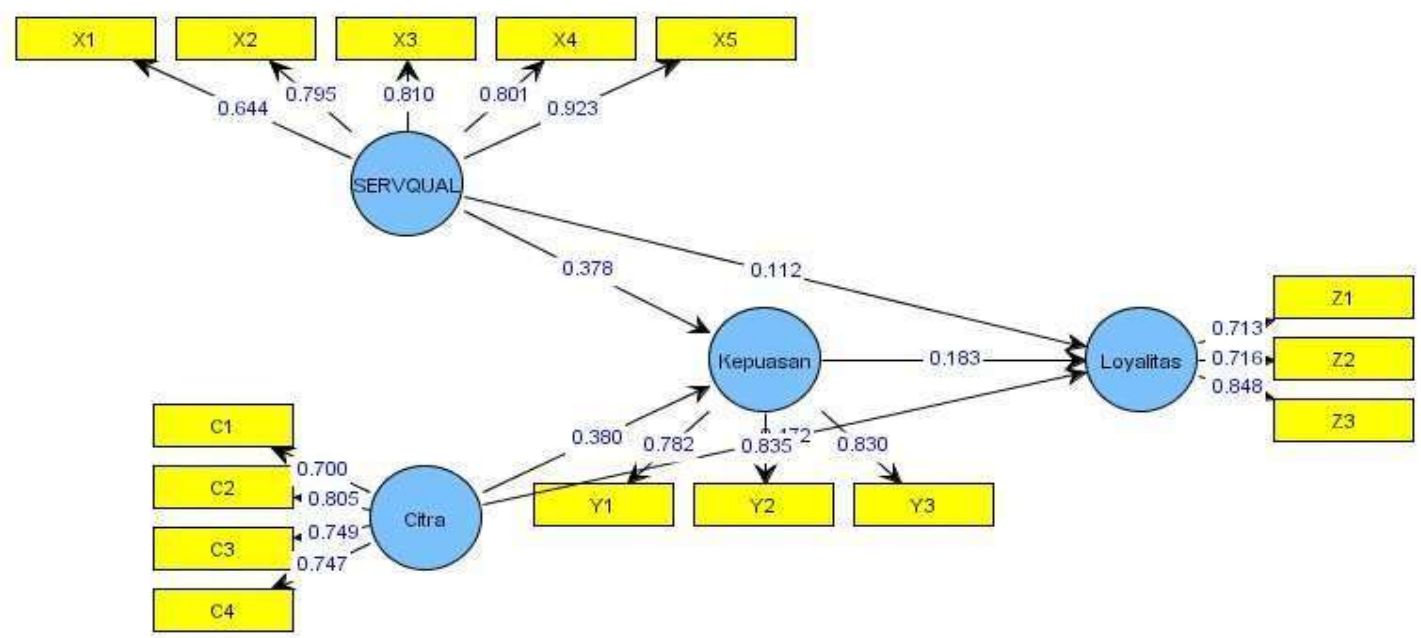

Berasarkah hasil analisis menggunakan analisis PLS maka pengaruh kualitas layanan dan citra organisasi terhadap kepuasan dan loyalitas anggota Koperasi Kredit CU Betang Asi dapat dilihat pada Tabel 2 berikut ini . 
Tabel 1. Pengaruh antar variabel

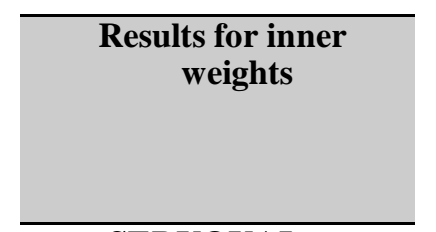

SERVQUAL ->

Kepuasan

\begin{tabular}{c}
\hline Citra -> Kepuasan \\
\hline SERVQUAL -> \\
Loyalitas \\
\hline Citra -> Loyalitas \\
\hline Kepuasan -> \\
Loyalitas
\end{tabular}

Sumber : Data diolah

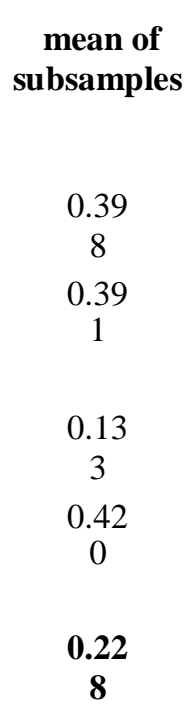

original sample estimate

0.37

8
0.38

0

0.11

2

0.47

2

0.18

3

\begin{tabular}{cc}
$\begin{array}{c}\text { Standard } \\
\text { deviation }\end{array}$ & $\begin{array}{c}\text { t- } \\
\text { Statisti } \\
\text { c }\end{array}$ \\
\hline $\begin{array}{c}0.08 \\
8\end{array}$ & $\mathbf{4 . 2 9 7}$ \\
\hline $\begin{array}{c}0.11 \\
1\end{array}$ & $\mathbf{3 . 4 1 2}$ \\
\hline $\begin{array}{c}0.16 \\
2\end{array}$ & \\
\hline $\begin{array}{c}0.15 \\
9\end{array}$ & $\mathbf{0 . 6 9 2}$ \\
\hline $\mathbf{0 . 2 0}$ & $\mathbf{2 . 9 7 1}$ \\
$\mathbf{7}$ & $\mathbf{0 . 8 8 5}$ \\
\hline
\end{tabular}

\begin{tabular}{cc}
$\begin{array}{c}\text { Standard } \\
\text { deviation }\end{array}$ & $\begin{array}{c}\text { t- } \\
\text { Statisti } \\
\text { c }\end{array}$ \\
\hline $\begin{array}{c}0.08 \\
8\end{array}$ & $\mathbf{4 . 2 9 7}$ \\
\hline $\begin{array}{c}0.11 \\
1\end{array}$ & $\mathbf{3 . 4 1 2}$ \\
\hline $\begin{array}{c}0.16 \\
2\end{array}$ & \\
\hline $\begin{array}{c}0.15 \\
9\end{array}$ & $\mathbf{0 . 6 9 2}$ \\
\hline $\mathbf{0 . 2 0}$ & $\mathbf{2 . 9 7 1}$ \\
$\mathbf{7}$ & $\mathbf{0 . 8 8 5}$ \\
\hline
\end{tabular}

\begin{tabular}{cc}
$\begin{array}{c}\text { Standard } \\
\text { deviation }\end{array}$ & $\begin{array}{c}\text { t- } \\
\text { Statisti } \\
\text { c }\end{array}$ \\
\hline $\begin{array}{c}0.08 \\
8\end{array}$ & $\mathbf{4 . 2 9 7}$ \\
\hline $\begin{array}{c}0.11 \\
1\end{array}$ & $\mathbf{3 . 4 1 2}$ \\
\hline $\begin{array}{c}0.16 \\
2\end{array}$ & \\
\hline $\begin{array}{c}0.15 \\
9\end{array}$ & $\mathbf{0 . 6 9 2}$ \\
\hline $\mathbf{0 . 2 0}$ & $\mathbf{2 . 9 7 1}$ \\
$\mathbf{7}$ & \\
\hline
\end{tabular}

0.20

$\mathbf{0 . 8 8 5}$

7

Hasil analisis membuktikan bahwa kualitas Layanan berpengaruh signifikan terhadap Kepuasan Anggota dengan nilai original sample estimate 0,378 dan t statistik 4,297> 1,967. Artinya semakin baik layanan yang diberikan maka tingkat kepuasan anggota akan meningkat juga. Demikian juga Citra organisasi berpengaruh signifikan terhadap kepuasan dengan nilai original sample estimate 0.380 dan $t$ statistik $3.412>1,967$ dan loyalitas anggota dengan nilai original sample estimate 0,472 dan t statistik 2,971> 1,967. Artinya jika Citra organisasi meningkat maka akan meningkatkan kepuasan dan loyalitas anggota.

Tabel 2. Pengaruh tidak langsung

\begin{tabular}{ccccc}
\hline Variabel & $\begin{array}{c}\text { Sampel } \\
\text { Asli }\end{array}$ & $\begin{array}{c}\text { Rata-rata } \\
\text { Sampel }\end{array}$ & $\begin{array}{c}\text { Standard } \\
\text { deviation }\end{array}$ & $\begin{array}{c}\text { T- } \\
\text { Statistic }\end{array}$ \\
SERVQUAL $>$ Kepuasan & $\downarrow$ & & & \\
Loyalitas & 0,084 & 0,093 & 0,060 & $\mathbf{1 , 1 8 3 4}$ \\
Citra $>$ Kepuasan $\perp$ Loyalitas & $\mathbf{0 , 0 2 7}$ & $\mathbf{0 , 0 8 1}$ & $\mathbf{0 . 0 9 2}$ & $\mathbf{1 , 8 1 2}$ \\
\hline Sund
\end{tabular}

Sumber: Data diolah

Hal ini perlu menjadi perhatian serius dari Kopdit CU Betang Asi untuk memperhatikan dan memelihara citra baik saat ini. Karena kopdit CU Betang Asi bergerak dibidang usaha yang membutuhkan kepercayaan dari anggota dan masyarakat. Jika terjadi hal-hal yang merusak kepercayaan maka anggota akan berpindah atau pergi meninggalkan Kopdit CU. Betang Asi.

Hasil analisis juga membuktikan bahwa kualitas layanan tidak berpengaruh signifikan terhadap loyalitas dengan nilai t statistik $0.692<\mathrm{t}$ tabel 1,96 demikian juga kepuasan anggota tidak berpengaruh terhadap loyalitas anggota dengan nilai t statistik $0.885<1,967$. Namun dilihat dari nilai original sample estimate pengaruh kualitas layanan dan kepuasan anggota terhadap loyalitas anggota adalah positif artinya bahwa kualitas layanan dan kepuasan anggota memiliki pengaruh positif terhadap loyalitas anggota namun tidak terbukti secara statistik. 
Kemungkinan penyebab kualitas layanan dan kepuasan anggota tidak mempengaruhi loyalitas tersebut karena anggota masih merasa hubungannya dengan organisasi sebagai sebagai pelanggan saja belum sebagai pemilik. Orientasi anggota untuk menjadi anggota CU Betang Asi lebih kepada mendapatkan keuntungan. Untuk memahami penyebabnya perlu dilakukan penelitian lebih lanjut misalnya dengan melakukan survei sejauhmana anggota rasa memiliki organisasi tersebut.

\section{KESIMPULAN}

Persepsi anggota bahwa pelayanan Koperasi Kredit CU Betang Asi sudah berkualitas diukur dari dimensi tangible, reliabilitas, responshipness, assurance dan emphaty, citra lembaga dinilai baik, anggota puas atas layanan yang diberikan dan anggota loyal terhadap lembaga.

Kualitas layanan berpengaruh positif signifikan terhadap kepuasan anggota, namun tidak berpengaruh terhadap loyalitas demikian juga kepuasan anggota tidak berpengaruh terhadap loyalitas anggota Koperasi Kredit CU Betang Asi. Citra lembaga berpengaruh signifikan terhadap kepuasan dan loyalitas anggota Koperasi Kredit CU Betang Asi.

\section{DAFTAR PUSTAKA}

Alma, Buchari.(2014). Manajemen Pemasaran dan Pemasaran Jasa. Bandung: Alfabeta. Anatan, Lina. 2008. Service Excellence - Competing Through Competitiveness. Alfabeta,Bandung.

Assauri, Sofjan.(2014). Manajemen Pemasaran. Jakarta: PT Raja Grafindo Persada.

Cahyani, Komang Indah Gita dan Gede Bayu Ranatha.(2015). Pengaruh Kualitas Layanan Terhadap Kepuasan dan Dampaknya pada Kepercayaan Serta Loyalitas. Fakultas Ekonomi dan Bisnis Universitas Udayana, Bali, Indonesia.

Devi, Ratih., Andi Sularso dan Arie Subagio. (2014). Pengaruh Bauran Pemasaran terhadap Keputusan dan Kepuasan Nasabah dalam Pengambilan Kredit PT. Bank Rakyat Indonesia (Persero) Cabang Jember. Artikel Ilmiah UNEJ.

Erwina Safitri1,Mintarti Rahayu2,Nur Khusniyah Indrawati (2014). Pengaruh Kualitas Pelayanan dan Citra Perusahaan Terhadap KepuasanPelanggan dan Loyalitas PelangganService Center [Studi Pada Pelanggan Samsung Service Center di Kota Malang]

Ferdinand, Augusty. (2014). Metode Penelitian Manajemen. Badan Penerbit Universitas Diponegoro, Semarang.

Foster, Bob. (2010). Pengaruh Kinerja Bauran Pemasaran Jasa terhadap Loyalitas Nasabah Penabung (Suatu Survai di Bank Central Asia Cabang Soekarno-Hatta Bandung). Jurnal Pendidikan Manajemen Bisnis, Vol.9 No.17, pp. 26-38.

Gardenia, Yulisa. (2009). Pengaruh Kepuasan Terhadap Loyalitas Nasabah Bank Universitas Gunadarma.

Jonathan, Sarwono. (2007). Analisis Jalur untuk Riset Bisnis dengan SPSS. Andi, Yogyakarta. Koestanto, Tri Hari. 2014. Pengaruh Kualitas Pelayanan Terhadap Kepuasan 
Seminar Nasional Penelitian dan Pengabdian kepada Masyarakat

Universitas Sang Bumi Ruwa Jurai Tahun 2020

Pelanggan Pada Bank Jatim Cabang Klampis Surabaya. Jurnal Ilmu \& Riset Manajemen Vol. 3 No. 10.

Kotler, Philip, dan Kevin Lane Keller. (2009). Manajemen Pemasaran Jilid 1, edisi Ketiga Belas, (Terjemahan Bob Sabran, MM). Penerbit Erlangga, Jakarta.

Lupi yoadi, Rambat dan Hamdani. (2006). Manajemen Pemasaran Jasa. Salemba Empat, Jakarta.

Mohammad, Haruna Isa.(2015). 7ps Marketing Mix And Retail Bank Customer Satisfaction In Northeast Nigeria British. Journal of Marketing Studies Vol.3, No.3, pp.71-88.

Mosahab, Rahim. (2010). Service Quality, Customer Satisfaction and Loyalty: A Test of Mediation. International Business Research Vol. 3, No. 4.

Nasution. (2004). Manajemen Jasa Terpadu (Total Service Management). Ghalia Indonesia, Jakarta 